\title{
Adiponectin Receptor Protein 1
}

National Cancer Institute

\section{Source}

National Cancer Institute. Adiponectin Receptor Protein 1. NCI Thesaurus. Code C103975.

Adiponectin receptor protein 1 (375 aa, $\sim 43 \mathrm{kDa}$ ) is encoded by the human ADIPOR1 gene. This protein is involved in adiponectin binding and signal transduction. 